DOI: https://doi.org/10.32653/CH1741002-1021

Lilit Simonyan

Cand. Sci. (History), Head of Archive

Institute of Archaeology and Ethnography

National Academy of Sciences of Armenia, Yerevan, Armenia

simonian_lilit@mail.ru

\title{
THE CULT AND COMMEMORATION \\ OF ST. VOSKEANS AND ST. SUKIASEANS IN THE LIGHT OF CAUCASIAN PARALLELS
}

\begin{abstract}
The cult of early Christian saints is related to poorly investigated data scattered in manuscripts and folklore sources. Historical ways of dissemination of Christianity in the region of the Caucasus and Western Armenia (South-West of Lake Van) and relationship between Armenian and Alanian Kingdoms in the 2nd century AD are the main subject of discussion in the article regarding the St. Voskeans and St. Sukiaseans. Interdisciplinary approach with compilation and comparison of all data including those of ethnography (sources and field study) allow to reconstruct historical reality and shed light on historical events of the period in question.

The obscure story about a group of early Christian saints of Alanian origin reports on existence of "grass-eaters" kind of Christianity in some regions of historical Armenia before the adoption of Christianity by the state. Since Sukias' name before baptism was Bahadras, we can trace some parallels in Armenian folk-lore and Caucasian epic of Narts. The center of the cult of St. Sukiaseans was Mount Sukavet until the beginning of the 2oth century. After its loss the former inhabitants of Alashkert founded a chapel with worship and pilgrimage in the village of Nerkin Getashen, although the legendary of the saints did not survive to this day in people's memory.

Source analysis allows to conclude that Alanian prince Bahadras-Sukias established a special kind of Christian movement of "grass-eaters" in the 2nd century AD that gained large popularity in the region of Bagrevand-Aghdznik-Vaspurakan and reached Vayots Dzor and Ararat. Their symbol was the Bahadras' cross (khach Patarazin in the Armenian epic "The Daredevils of Sasun") and their monasteries formally belonged to the Armenian Apostolic Church.

Keywords: St. Sukiaseans; early Christianity; grass-eaters; Bahadras; Providential Cross.
\end{abstract}

(C) Simonyan L., 2021

(C) Daghestan Federal Research Centre of RAS, 2021 
DOI: https://doi.org/10.32653/CH1741002-1021

Симонян Лилит

к.и.н., зав. архивом

Институт археологии и этнографии

Национальной Академии наук Армении, Ереван, Армения

simonian_lilit@mail.ru

\title{
КУЛЬТ И ПАМЯТЬ СВ. ВОСКЕАНОВ И СВ. СУАКИАСЯНОВ В СВЕТЕ КАВКАЗСКИХ ПАРАЛЛЕЛЕЙ
}

\begin{abstract}
Аннотация. Культ раннехристианских святых связан со слабо изученными данными, рассеянными в рукописях и фольклорных источниках. Главным предметом статьи являются исторические пути распространения христианства на Кавказе и в Западной Армении (к юго-востоку от озера Ван) и взаимоотношения между Армянским и Аланским царствами во II в. н. э. относительно Св. Воскеанов и Св. Сукиасянов. Междисциплинарный подход при компиляции и сравнительном изучении всех данных, включая этнографические (источники и полевые исследования), позволяет реконструировать историческую реальность и осветить исторические события данного периода. Не вполне ясная история о группе раннехристианских святых аланского происхождения сообщает о существовании «травоядной» ветви христианства в некоторых регионах исторической Армении до принятия государственного христианства. Поскольку имя лидера группы Сукиаса до крещения было Бахадрас, можно провести некоторые параллели в армянском фольклоре и в кавказском Эпосе о Нартах. Центром культа святых Сукиасянов до начала XX в. была гора Сукавет. После ее утраты бывшие жители Алашкерта основали часовню с живым культом и паломничеством в селе Неркин Геташен, хотя легендарная история святых не дошла до наших времен в памяти людей. Анализ всех источников позволяет заключить, что аланский принц Бахадрас-Сукиас основал во II в. особую ветвь христианского движения («травоеды»), которая обрела широкую известность в регионе Багреванд-Ахдзник-Васпуракан и распространилась до Вайоц Дзора и Арарата. Символом травоедов был крест Бахадраса (хач Патаразин в армянском эпосе «Сасунские удальцы»), а их монастыри формально принадлежали Армянской Апостольской Церкви.

Ключевые слова: Св. Сукиасяны; раннее христианство; травоеды; Бахадрас; Возвещающий Крест.
\end{abstract}

(C) Симонян Лилит, 2021

(c) Дагестанский федеральный исследовательский центр РАН, 2021 


\section{Commemoration}

The Calendar of Feasts of the Armenian Apostolic Church (Tonatsuyts) preserved the dates of the celebration of two groups of saints named Voskeans and Suk'iaseans. These are movable (?) feasts commemorated on the next Tuesday (Sukiaseans) and Thursday (Voskeans) after the Arajavorats Lent and both occur mostly in February [1, 73-111]. These dates are associated with the historical period following the calendar reform of Simeon Yerevantsi. Thus e. g. the Calendar of 1774 has those dates along with accompanying chants [2, p. 52-53]. Gh. Alishan mentions the period (season) of

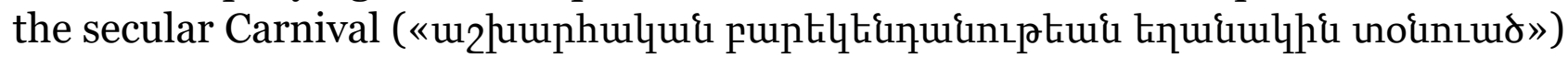
[3, p. 59], considering Barekendan-Carnival mostly occurring in February, as well. On the opposite, the Calendar of 1725 has August 27 as the day of commemoration of the saints Voskeans and Sukiaseans [4, p. 264]. The same date can be observed in much older manuscripts of the Synaxary along with the Armenian date of Navasardi 17 , as well as in printed versions of the Synaxary [5, p. 42-43].

Nowadays the Russian and the Georgian Orthodox Churches accept a saint with the name Sukhiy, Sukkia, or Isikhiy Mesukeviyskiy (i.e. Mesukevian - a distorted version of the name of mountain Sukavet, Georgian "Sukaketi", see below) with the commemoration date on April 25. The main source of data on that saint and his companions - Mesukevian martyrs - is a manuscript, preserved in the Georgian language in the Iveron Monastery (Our Lady of the Gate) on Mount Athos, Greece (the primary source has never been published), presumably, a Georgian translation of the Armenian original hagiography. Recently, A. Sofyan [6, p. 149-151] revised the hagiography of Sukhiya and 16 Georgian companions based on the new non-scientific publication in 2011 [7, p. 204] of the Iveron Monastery manuscript. The author focuses mainly on pseudohistorical questions such as why should the Alanian governor send a military commander after the ordinary people, or which historical king is hidden under the image of Artashes, as well as on discrepancy between the Armenian and Georgian texts. Unfortunately, she does not tackle any issues concerning the cult and its modern manifestations. The most considerable difference is that in the Georgian manuscript the land of Aluank (now Azerbaijan) is indicated as the homeland of St. Sukias and his companions, while all the Armenian sources insist on the Alanian origin of the Sukiaseans.

\section{Chronicles and legendary story}

Some forms of folk-Christian worship of those groups of saints have been known this far only in the region next to the city of Vałarshakert (later - Alashkert, now Eleşkirt in Turkey), and an investigation is needed to explain how much popular the aforementioned saints were and what half-historical legendary story has been associated with them.

Voskeans and Sukiaseans are mentioned in the chronicles of only two church historians - Thovma Arcruni and Hovhannes Draskhanakertc' $i$, both of them belonging to the 1oth century AD. 
Thovma Arcruni refers to saints living on mount Sukavet, who visited the Queen Satenik - their compatriot and blood relative - while she dwelled in the region of Van, judging from Thovma's previous fable, in the city named Artamat (most probably, the later village Artamet). They criticized the cult of idols as nonsensical in the way saint K'rius did before her spouse, King Artashes. Their words impressed the queen but she was not ready to openly stop worshipping the idol of Asttik, erected earlier by her husband. Thovma then admits his lack of knowledge about the further events [8, p. 57-58].

Obviously, K'rius (Gr. xpvoós, Golden) is the same person with Voski (Arm. nulh, woski, gold), who is mentioned by Hovhannes Draskhanakertc'i and other sources (see below), and the saints from the mountain Sukavet, the queen's blood relatives, are St. Sukiaseans.

Hovhannes Draskhanakertc $i$, or Hovhannes the Catholicos presents another version: according to his History, some apprentices of St. Thaddeus, after the martyrdom of their teacher, under the leadership of Voski who led ascetic life by the source of Euphrates and baptized some followers of their doctrine in its water, also baptized several Alans who were relatives of the queen Satenik, the spouse of the king Artashes. But the queen's sons got jealous about the deal and Voski paid his life for that together with his friends (companions?). The baptized relatives of Satenik left the place and migrated to Mount Jrabashkh (lit. "providing water") where they lived ascetic life, eating only grass. During some time, their dresses turned into tatters and hair-dress (??) ascended from heaven to cover their nudity. Thus they resembled wild goats and were named "k'oshik" (dial. "goat"). Later a man called Barlaha (var. Barahla, Barlah) came from the kingdom of Alans to find them and after some interrogation killed the hermits. Mount Jrabashkh was named Sukav after the name of the martyrs' leader, Sukias [9, p. 24-25]. Late sources mention the new name of Sukav(et) - K'osadagh - which obviously is a Turkish name meaning "Bald mountain" [10, p. 117], but Gh. Inchichean (and after him Gh. Alishan) explains it as a distortion of "K'oshik", the nickname of Sukiaseans [11, p. 536] .

These two stories, in almost no point connected to each other, may be "restored" with the help of more recent writings like texts of Synaxaries and Collections of Preaching (Č́arəntir). M. Avgerian compiled them together and presented them as a full hagiography in two parts - the story of Voskeans and that of Sukiaseans [12, p. 121-133, 90-120].

According to that compilation, Voski was a Greek or a Roman who accompanied the Saint Apostle Thaddeus on his way through Armenia with his 5 friends (friends or companions?). After the death of the Apostle, they once visited king Artashes and preached to him, to the queen Satenik and to her relatives who lived in the courtyard. The king was engaged in a war and had no time for religious discussions, but the royal Alans were impressed by the speech of the newcomers, and they decided to be baptized. Voski baptized the relative of the queen named Barak'ada, Barak'adra, or Bahadras with 80 or 90 others in the source of the River Euphrates. Barak'adaBahadras acquired the new name of Suk'ias, meaning "calm, peaceful", while 
other Alans received Greek or Roman names, as well. Although only 17 names of Sukiaseans are listed in Avgerian's sources, and no name for Voskeans except Voski himself, sources insist on 80-90 baptized people. Every one of them saw the image of Christ over the hill in front of the spring (the source of Euphrates), and later the place was named Aveteac xach - Providential Cross [12, p. 91-92]. The case (?) inspired jealousy by the queen's sons Vəro (Vərdo) and Vəno who informed their father Artashes and elder brother Artavazd. One variant of the story tells that the king Artashes exiled Voskeans, but Sukiaseans followed them [12, p. 125]. Artavazd and his brothers tried to persuade Sukiaseans to drop Christianity and come back to their royal status, then they tried to make Voski convince the newly baptized, but to no avail, because Sukias and at least some of Sukiaseans were of royal blood and their own blood relatives, Satenik's sons could not approach their uncles, so Artavazd sent his servants to kill Voski and his friends, and they slaughtered them. After the death of Voskeans, Sukiaseans moved to Mount Jrabashkh near the city Baguan (obviously, the same as later Alashkert) and stayed there for 43 or 44 years in strict chastity. With their sincere prayer, they prevented a war between Persians and Armenians. Once they had an idea to go and destroy the heathen shrines of the city, but a vision (or a dream) of one of them - Poloktes - held them back. Probably, that same intention to destroy the shrines is illustrated in the chronicle of Thovma Artsruni as a discussion with the queen about the cult of idols. Then another vision of Poloktes predicted that a lion would come from the land of Alans and he would find them. In reality, a warrior named Barlaha, or Barlahael was sent by the king of Alans to bring back the "deserters". Stumbling on their stubborn resistance, the king's envoy killed them and threw their bodies into a crevice. Many years later St. Gregory the Illuminator found their bones and established a martyrium on the place where the saints perished as witnesses to the Christian faith. As they died on Navasardi 17 AD 130 or 140 [12, p. 98], the date was accepted as their commemoration day.

In addition, M. Avgerian cites another story about the junior members of the Sukiasean group, Jacob and Theodosius, who managed to escape from Barlaha's persecution, came back to the place of martyrdom of their friends, found stains of blood on the ground and put stones at that place. Jacob and Theodosius continued to live there for some years. After their death, they were buried at the place where the fortress of Alashkert was built later on [12, p. 110-111].

Gh. Alishan pays attention to different information from certain manuscripts of Č'arəntir (Collection of Speeches) and Haysmavurk' (Synaxary), the sources of which are of Greek origin (probably, Tatianus and/or Valantianus (?) named in some manuscripts). He claims that Voski - K'rius, or maybe Aurelian - and his group were ministers from Rome who met St. Thaddeus' apprentices in Armenia, dressed in a somewhat alien way, and tested them to make sure if they really represented a Christian movement. After the meal made of a deer called by St. Taddeus, and its miraculous reanimation by the apostle, the Roman envoys adopted Christianity becoming baptized by St. Thaddeus. The apostle also ordained K'rius as a priest. Then K'rius and his friends visited king Artashes with the purpose of fulfilling their duty as 
ministers and simultaneously realizing the mission of preaching Christianity to the noble. Then Alishan presents the same topic discussed by M. Avgerian on preaching to the king, the queen and her Alanian relatives; the jealousy of Vəroy (Alishan identifies Vəroy with the poet Vəroyr mentioned by Movses Khorenatsi) and Vəndoy and the baptism of Bahadras or Barak'adr with 19 other royal Alans [3, p. 61-63]. However, there is a significant addition in the manuscript investigated by Alishan as compared to that of Avgerian: the name of the persecutor Barlaha is translated as "The Paradise of God", and the name of the Alanian king who sent him was Gigian [3, p. 64].

Gh. Alishan also mentions a story of two friends of the Sukiaseans, who having escaped from Sukavet, lived and deceased on the hill, where Vałarshakert was built later on. Their bodies were found by hunters who buried them on the hill not far from the valley; later their graves became a famous healing site [11, p. 536]. Probably that is the same place as described in a Collection of Speeches (Čharontir), cited by Gh. Inchichean as relating to Voskeans. It was the same place where the Sukiaseans reached them with the purpose of learning Christian creed; and where later the city of Vałarshakert, home for the king's sons, was built. Apparently the same mountain or another peak of the same range was also called Shahapivan $\left(\mathrm{k}^{k}\right)$. This name comes from that of duce (дуче? Итальянский титул?) Shahap Gnuni and reflects the existence of a significant monastery $\left(v^{2} k^{6}\right)$ where the king's troops gathered together [13, p. 406, $414 ; 11$, p. 536]. In his earlier work, Inchichean gives a different name - Tsakhkats, or Korduhats mountain [10, p. 16].

This last fact is important because of folk legends connected to the hill not far from the city of Alashkert to be discussed below.

\section{The Monasteries and Folk-Christian worship}

The legendary story about the martyrs of Alanian origin is of great interest, because it, in some way, connects the mythical information about Queen Satenik and her son Artavazd to the early Christian history of Armenia, which simultaneously expands the geography of influence of Alans upon the Armenian history - at least on the legendary level.

The fact is that the story about the Sukiaseans survived for many centuries and was still told among people by the end of the 19th century. Many places in the region of Bagrevand were connected to the characters in that story. At least two sources testify to its distribution among the Armenian population in the form of folk legends.

H. Tataryan informs that a "couple" of monasteries - of St. Voskeans to the West from Bayazit and of St. Sukiaseans on Mount Sukavet - were preserved as places of pilgrimage and were connected with folk legends [14, p. 1]. According to the folk variant of the story, five Greeks and their leader K'rius heard the preaching of St. Thaddeus and accepted Christianity. In their turn, they went on spreading the teachings of the Nazarene and baptized people in the name of the Holy Trinity. The Voskeans even reached Artashat (the capital city of Artashes - L. S.) and were welcomed by a rich man named Artashes and his spouse Satinik, a woman of Alanian origin. Some of her 
relatives, the name of one of which being Bahadras, converted to Christianity. For that reason, they were persecuted by pagan Artashes and were compelled to leave the city along with the Voskeans. Then the cursed son of Artashes - Artavazd killed the Voskeans. As for Sukiasians (Sukiaseans? Sukiasyans?), they lived in the desert place for 44 more years and were killed in the times of the heathen king Shapur.

There was even a song about them reflecting the events of the same story:

In the desert place,

On mount Catkavet,

In the deep gorge

They were baptized

In the source of Euphrates,

Where waters mix.

They were nineteen

Together with Sukias.

Although there is a little misapprehension - Artamat in Vaspurakan is confused with Artashat in Ararat valley - this is almost the same story as that of chronicles. What appears only in Synaxaries and folk legends is the name of Sukias before baptism - Barak'ada, or Bahadras.

In all cases, there are mentions and even descriptions of sacred places associated with St. Voskeans and Sukiaseans, which were built in province Bagrevand, in the mountains.

The Monastery of the St. Voskeans was placed in the valley under-Mount Ala Dagh, that is the same as Całkeats, or Całkavet mountain. About half a mile to the North two branches of Euphrates intertwine (as in the song - "waters mix"), and that is the place where Voskeans resided before leaving their refuge. It should be noted that in the earliest text of Armenian Geography (Ashxarhac'oyts) dating back to the $5^{\text {th }}$ century $\mathrm{AD}$ according to most authors, the source of the River Aracani (now Murat) on the peak of Całkotn is called Voskik' [15, p. 34] without any mentions of VoskiK'rius or other saints. Gh. Inchichean relying upon a text from Č'ar $\square$ ntir, agrees that the place chosen by St. Voskeans was near the source of Euphrates and Mount Calke [13, p. 413].

Tradition ascribes the foundation of the monastery to St. Gregory the Illuminator who also established the tradition of pilgrimage to the place, which continued at least until the end of the 19th century, while the monastery remained inhabited until the beginning of the 19th century [14, p. 1]. Before St. Gregory's first visit to the monastery, however, a martyrium, or a chapel existed there. Its foundation is ascribed to St. Thaddeus, who raised the so-called Avetiac' ("Providential") xach, the same cross mentioned in the legend provided by Avgerian.

There is a local story about a pilgrim who visited the prominent monastery of St. Jacob on the slope of Mount Masis (Ararat) and was advised to go to Sukav (another high mountain, the name of which is associated with St. Sukiaseans) or to St. Voski. 
Thus, the St. Voskeans monastery was a well-known sanctuary until 1840 . Afterwards the meaning of the monastery gradually diminished. By the end of the 19th century most of the Armenian population of the region had left their usual habitat, and only casual visitors still passed by the abandoned monastery or rather its ruins [14, p. 1].

The monastery of the St. Sukiaseans had a slightly different destiny. Placed at the eastern side of the mountain Minor Sukav(et), 3 hours north-west from Toprakkale near the village Molla Suleyman, the area remained inhabited by Armenians in the 19th century. Correspondingly, the monastery remained a vital pilgrimage site until the beginning of the 2oth century. Pilgrims visited the half-ruined monastery during the festivals of Vardavar in summer and St. George in early autumn (end of September). The people of Molla Suleyman being Catholic Armenians even used to serve liturgies in the churches of the monastery [14, p. 1]. Gh. Inchichean points at different feasts for pilgrimage - Dormation of St. Mother of God and Escalation of the Cross [10, p. 117], despite the fact that the seasons almost coincide-summer and early autumn.

Some information is given by S. Haykuni, whose data relate to approximately the same period as that of Tatarian [16, p. 108-111]: On the south-eastern side of Sukavet two chapels of human's height made of rough stones were built. That was the place of martyrdom of the St. Sukiaseans. One of the chapels served for Gregorian, the other - for Catholic Armenians as a church, and liturgies were served there. Many people visited the place as pilgrims. There was a big stone, on which, according to local tradition, the saints were killed. Young girls and boys gathered around the stone and threw little pebbles on it. If a pebble stayed on the big stone, it meant that the wish of the thrower would come true. Another big stone was put on the Lusaghbyur (Light, or Holy Spring). They believed that the spring would get dry if a bad man approached it. There were also several holy caverns. People believed those were the places where the St. Sukiaseans prayed.

Inchichean supposedly describes the same big stone as the marker of the place where the Sukiaseans were beheaded. Moreover, he adds an important detail according to which the stone was covered with drops of their blood [10, p. 117]. There is a rare evidence of the same or another sacred stone on the peak of Sukavet - with a hole in the middle - where childless women used to come and pass through it to be able to get pregnant [17, p. 1].

In regard to the source drying up, the folk belief is a reminiscence of the fragment in Synaxary, telling that a source sprang out of the saints' shed blood. Every year on their commemoration day it springs again and heals many diseases, especially leprosy, and then disappears for the whole year [11, p. 537].

According to the legend recorded by Haykuni, a group of 40 bandits met St. Thaddeus and wanted to rob him. The saint preached Christian morals to them, but they demanded that he called a wild deer. If the deer did not appear, they would kill him instead of the animal. A deer came, and the bandits adopted the true Christian faith. The 40 robbers were the St. Sukiaseans. St. Thaddeus baptized them. Then he sent 10 of them to the village called Ghlich-Ketuki, 10 - to the village Amat, 
10 - to mount Aladagh, and 10 of them stayed at Sukavet. The local heathen authorities were looking for the neophytes. Inhabitants of the village Khastur not only showed the place where the St. Sukiasians lived, but also accompanied officers with dhol and zurna (drum and trumpet). Later other residents of Alashkert started to call them "betrayers of virgins" [16, p. 111].

A different tradition connects the St. Sukiaseans with one of the most popular Armenian saints - St. Sargis. St. Sargis' sanctuary to the west of Alashkert fortress had its own legend. According to it, when the Alashkert castle was attacked by a foreign king, a hero named Sargis yielded himself to the conqueror in order to release the people. However, after the king tortured Sargis, people started a strong resistance and finally won the battle. They believed that Sargis was a friend of the Sukiaseans. While the other Sukiaseans had accepted the wrath of martyrdom, Sargis managed to escape from Mount Sukavet, but was later killed at the place of the future fortress [18, p. 36].

Matthews of Edessa also informs about a saint named Sargis martyred in the times of Gagik the Second, the last king of the Bargratuni dynasty, by the hands of Hagar's or Mahmed's sons (i.e. Arabs-Moslems) in the region of Bagrevand [19, p. 117]. The people's memory united that martyr with St. Sukiaseans.

In conclusion, it can be said that while the place and motivation of the saints' martyrdom have remained the same, the historical context has fully changed. Such an ambiguity testifies the existence of several folkloric variants of the same story. In every case, the issue cannot be related to the generally worshipped St. Sargis the Warrior, whose feast are also commemorated in winter .

There was a pilgrimage site devoted to St. George in Bagrevand, not far from Davoy village. During the festival of St. George in autumn, a huge crowd of people visited the holy site. There were three giant ivies and a source there, where offerings were given. People of Bagrevand, the main visitors of the place, considered the saint to be a friend of the St. Sukiaseans. According to a local legend, as the Sukiaseans parted from the St. Voskeans on Aladagh mountain, they wandered through the mountains, before they found their new home at K'osadagh. Here Gevorg (George) fell ill and stayed with one of his friends, while the others left. When Gevorg died, he was buried there. After his death, his friend reached Zetikan, where the people of Khastur helped the officers to catch him [16, p. 201-204].

The richest description of the pilgrimage to Sukavet belongs to G. Hakobyan. It reflects the situation just before the Great Genocide of 1915. Hakobyan reports that not only the whole Armenian population of Bagrevand, but also that of Basen participated in that pilgrimage. There were some pilgrims from Khnus and Manazkert, too. On the day preceding the pilgrimage, Armutli village got ready for a long journey: old women and children on carts, old men - on horses and donkeys, and the youth - on foot gathered together bringing rams and male goats, cocks, domestic and wild doves for sacrifice, as well as fresh-baked bread and other meal. Their procession resembled a joyful parade, accompanied by musicians. Just before the sunrise, the crowd from Armutli united with the group of pilgrims from other villages at the bottom of the 
mountain. On Sunday morning Sukavet was surrounded by multiple pilgrims from different places: even Russian soldiers joined them and participated in festivities. Pilgrims from Basen and Alashkert had various places for sacrifice offerings [20, p. 109-110].

In 1873 a burial of saints (or hermits) was occasionally discovered not far from the Armenian village of Kondemir and Kurd village of Inalu in Western Armenia (Turkey), in the region of Taron, neighboring Alashkert. Inhabitants of Kondemir were in haste to inform the servants of St. Karapet Monastery of Mush about the discovery of St. Sukiaseans's tomb. The Armenian inscription on the tombstone was deciphered by a cleric expert, and contained no special reminiscence of St. Sukias or of his companions [21, p. 135-138]. This curious event once again indicates the wide distribution of the cult in the 1800 s.

Apparently, the tradition of pilgrimage to the places connected with the St. Sukiaseans ceased after 1915, for the provinces Alashkert (Bagrevand), Basen, Khnus were cleared of Armenians.

Still there remains a range of questions around that history and the objects of worship and pilgrimage. One of these questions is: did the cult or at least mythology of Sukias, Voski and their friends-martyrs reach other regions of historical Armenia in other ways than through the official Church and its feasts? Since the leader of Sukiaseans was of Alanian origin and carried the name Bahadras, the second question is: was the role of the Alanian preachers with their Providential Cross significant for further distribution of Christianity in Armenia in the Early Middle Age? Another Alanian name in the legend belongs to the Queen Satenik, or Satinik, and the third one is that of the persecutor - Barlaha, whose name sounds non-Caucasian, and most probably, of Assyrian origin; however, it is translated as "The God's paradise". Finally, the name of the Alanian king Gigian sounds Greek (Gigin?). Does that mean that there are false names in the texts or do they belong to real historical figures?

\section{St. Sukiaseans and Caucasian Characters}

We have to distinguish history and myth, although that is the nature of epic narrations to fuse true stories with some portion of a miracle. Very little is known about Artashes the king as a historical figure. Most texts mentioning him and his deeds are pure myths. The stories of his marriage, relations between his sons and his in-laws to a proper extent resemble the plots of the Caucasian Epic of Narts [22, p. 51-55]. This in no way means that just the "history" of Artashes was reflected in the Epic of Narts or that the North Caucasian epic is of Armenian origin as A. Petrosian believes [23, p. 10]. The fact is that nobody has ever recorded a single variant of the Epic of Narts or even a puny fragment of it or a little motif in a fairy-tale in any Armenian dialect or from a narrator-Armenian. The justifications that the Armenians might have forgotten it during centuries, or it was in any way wiped, or not found, are inappropriate. Parallels between the Armenian and North Caucasian epics and mythology concerned many Armenian authors of the 19-20th centuries, who were 
interested in finding such narrations (if any). On the other hand, nothing prevented the Armenians from preserving multiple local variants of "Shah-Name", "Leyli and Mejnun”, "Kyor Oghli", "Khan Dəmdəm" etc., fully realizing their foreign origin but having developed them originally.

What we know for sure is that some epic songs about the Armenian queen of Alan origin - Satenik - were popular among Armenian bards of the Golt'n region in the times of Movses Khorenaci. Some of those songs might have had a North-Caucasian origin. The only source of Satenik - the Alan princess - different from the fragments of those epic songs recorded by Movses Khorenaci is the history of Christian martyrs from Mount Sukavet. There are no Caucasian parallels to that story in folklore materials yet (except Iveron monastery's Georgian text). Thus, Christian legends about Satenik's relatives-martyrs might be purely Armenian in core - or might be not. The question is whether there are any historical grounds in these stories.

The story connects at least two cultures, and there must be coincidences other than just personal names, too.

One important remark of M. Abeghian concerning the legendary Khach Patrazin (xach pat[a]razin) - an apotropaic cross of the Daredevils of Sasun [24, p. 843] is worth mentioning here:

"The etymology of Patrazin or patarazin is unclear. It has common Minor Asian or Caucasian character (comp. the name of the Ossetian (=Alan) folk epic's hero Batraz, Patraz or Pataraz, being falsely etymologized as Bat'r-as, i. e. Ossetian brave man, there is a Hittite name Pataraz, etc.). It (Khach Patrazin - L. S.) is presented as a cross tied or stamped on a hero's arm playing the role of a talisman (hamayil, magic protection) and is called just "hamayil holy cross" ... That cross gives great might to the hero and protects him from strikes".

The other form of the same symbolic object is Khach Paterazmi (the Cross of the War). Another reminiscence of the latter can be found in late Medieval apotropaic scroll-scripts, Hmayils. In the list of Holy Symbols (surb nəshan, i. e. places where a fragment of the Holy Cross of Jesus' crucifixion is kept) that cross is mentioned along with Varag's, Getargel's and other famous holy symbols in Hakob Meghapart's Urbatagirk [25, Vasn Gani]. Thus, "khach patarazi" of the epic may seem a distorted form of Paterazmi Surb Nəshan of Hmayils. However, we do not know much more about the Paterazmi Holy Symbol than about the pat[a]razi cross of the epic. The monastery where it was probably stored - the Sk'anchelagorc (Yerashxavor) Surb Nəshan of Artske, not far from the lake Van, - in fact was once a frequently visited sacral place. Only several literal sources [26, p. 192, 226] and no ethnographic or traveler's note refer to the Holy Symbol of Artske under that name. Authors, mentioning ritual performing of the Sk'anchelagorc Holy Symbol that gave its name to the monastery, testify that the Sign was carried through locations in case of pandemics of plague or other transmissible diseases [27, p. 269; 28, p. 42] and they insist on the tradition of Holy Symbol being not a fragment of the Holy Cross, but of the basin where the Child Jesus was bathed. Thus, it could not be considered as a real surb nəshan . The origination of the name Khach Paterazmi remains enigmatic: it is even unclear what 
actually connected it with war. Therefore, we have no credible data and not enough reasons to identify pat[a]razi cross with the Sk'anchelagorc Holy Symbol.

If we tried to compare the symbol of Pat[a]razin cross with that of Batradz's sword, this would lead to a deeper investigation. It is obvious that the typically Christian apotropaic symbol could in no way be the same as the sword of Batradz of the NorthCaucasian epic, particularly considering that there is a cycle of Armenian myths around King Prosh's (or Bro's) sword with the same final scene with throwing the wonderful Havluni sword into a lake: Srvandztiants [29, p. 394-395] and Lalayan [30, p. 149-153] mention Nazika lake, but Bense [31, p. 13-14] and Shahinyan [32, p. 175-177] mention Xachlva lake, the latter name meaning literally "washing the cross" and duplicating the name of a Christian ritual of water consecration - xachalva as placing an object containing a fragment of the Holy Cross into water [33, p. 85]. Now, is this geographical name and the myth connected with it a manifestation of the symbol of sword-cross? [34, p. 68-72]

For the legendary cycle about King Prosh, the motif of throwing the mighty sword into the lake is a solid one, while, in comparison, the same motif [35, p. 21], largely discussed in G. Dumezil's and J. Griswar's analysis [22; 36], is not typical for the epic cycle of Batradz. Usually, researchers do not include Armenian material in their investigations of parallels between the Caucasian epic and Arthurian cycle and restrict themselves in the frame of Ossetian variants of the epic cycle around Batradz [38, p. 105-106], although some historical ways of passing the story about the miraculous sword have more ground.

Another possibility still remains that the etymology (the "false" one as M. Abeghian believes) of the name Batradz (and, consequently, Bahadras) may be traced to Central Asian, Mongolian sources. Specifically, V. Abaev considers the names of Batradz and his father Khamits to be a result of "splitting" the name of Mongolian hero - Xabichi Bahatur [39, p. 18] (comp. also the Chechenian form of Batradz's name - Xamchi Pataraz that is even more resembling the Armenian xach Patarazin). In that case, it should on the one hand be proved that the image of Mongolian Khabichi (in Sacral Saga of the Mongols he is in some translations mentioned as Bahatur, but never Bahadras or Batradz) can be identified or corresponds to that of Ossetian Batradz, but that is not quite certain. On the other hand, however, at least 5 of 7 sons of Mongolian Khabichi have names containing the particle "xach" - Xachikuyluk, Xachin, Xachiu etc. [40, p. 6]. Nevertheless, such resemblances - coincidences or not - do not cross the border of pure linguistics and are not supported by parallels in folklore.

One rare evidence brings back to the topic of "sword and cross": the Armenian writer Seylan in his historical-ethnographic review "Sasun" (the homeland of the heroes of the Armenian epic) describes in detail a sacral place called Xasht'rik in a cave of a mountain [41, p. 646-647]. The main object of worship in the sanctuary was the cross made of a rusty sword, stuck in a cubical marble obelisk. Khashtrik - obviously a diminutive form of xach-t'ur (cross-sword) - has been worshipped quite independently from the official church. Nevertheless, it was considered the holiest place in Sasun along with the ruined monastery Maratuk St. Mother of God 
- the most significant sacral site of the epic "Daredevils of Sasun". Could its second name be Khach Patarazi or Khach Paterazmi? There is too little data to answer this question. But Xasht'rik is a material incorporation of the mythical motif of "a sword in/from the stone" and not an apotropaic arm tie or a stamp. It resembles more the Providential Cross of Voskeans-Sukiaseans, but no source contains any hint that the St. Sukiaseans' cross was made of a sword .

Nevertheless, there are some other evidences of the reference between "The Daredevils of Sasun" and the legend of St. Sukiaseans. The well-known narrator Nərgey Hako from the village of Yeranos (Gegharkunik region) whose family had immigrated from the over-mentioned village Khastur near Alashkert, used to tell the epic in his own artistic way, adding to the main plot some other myths and legends. One of those legends was the story about Christian Sukias and the Egyptian pharaoh, unfortunately, cut out by M. Abeghian and not included in the publication [24, p. 9-11].

However, the Cross of Pat[a]raz, when identifying Pataraz, Batradz, and Bahadras as variants of the same personal name, may refer not to the hero of the Ossetian epic, but to St. Sukias, to the Christian martyr with the same name, Bahadras. Thus, the symbolic cross of the Armenian epic heroes could be a reminiscence of the Aveteac xach over the source of Euphrates - of Bahadras' Cross. The Providential Cross of St. Voskeans and Sukiaseans could be a wooden object or a former sword, and therefore, any other object containing a fragment of that cross would acquire sacral functions and become an apotropaic item. Such an object could be transported to neighboring places and reach even southern regions, being used in baptism ceremonies. The mentioning of 80-90 people baptized people in the source of Euphrates could mean that St. Voskeans and then St. Sukiaseans not only lived on Mount Sukavet, pursuing chastity, but also preached and baptized in the name of the Providential Cross - the Cross of Bahadras, xach Patarazin.

If we suppose that xach Patarazin is in any way connected with Khashtrik and Bahadras-Sukias's Providential Cross and take into consideration that the motif of that cross is characteristic just to the variants of the "Daredevils of Sasun" spread and recorded in the regions from Alashkert to Moks, Shatakh and Sparkert in the south, it would give reasons for speculations. St. Sukiaseans spent more than 40 years on Mount Sukavet, and it is quite reasonable to assume that they had a missionary activity. As all the sources insist, the saints pursued ascetic life, eating grass and being covered with fur. That is why their nickname was $\mathrm{k}^{\prime}$ oshik. One of the indirect proofs of their mission is the way of life as grass eaters, while there are some testimonies of the existence of that form of monastic unions in Armenia. Even some monasteries carry that name. One survived example is Xotakerac Surb Nəshan, or K'arakop' monastery near the village Khachik in Vayots Dzor in contemporary Armenia. The name derives from hermits - xotakers (lit. "grass-eaters") who once inhabited the region and owned a Xotakerac Cross [44, p. 280]. G. Hovsepian wonders how that article (item?) could have later become the property of the Proshean royal dynasty [45, p. 40]. 
Another mentioning of grass-eaters can be found in "The History of Taron" by Hovhan Mamikonean. The history actually begins with the letter of St. Gregory the Illuminator to Łevond, bishop of Caesarea, where he informs about two "living witnesses of Christ, Anton and Kronides" who lived in the place named Innaknya [46, p. 8], and in his response Łevond promises to send Epyphan and forty other abstainers - apprentices of St. Anton [46, p. 10]. Then it is described how king Trdat went to see those hermits. The ascetics lived in the forest, so it took some time before the servants of the king heard them singing in the morning on Sunny hill where earlier the sacrifice place of the deity Demeter was located. Then they greeted Anton, one of the hermits, and he gave them avetis (good news) about the destruction of the evil spirit by God. That is why the hill was called Aveteac bəlur. Then the servants were sent to the slope of Mount Arjan by bishop Albianos, and they brought the avetis to the king. The king ordered to gather stones and erected a sign of the cross on the place where avetis was given, and its name remained Aveteac xach [46, p. 41]. This somewhat naive "explanation" does not reveal the reality of the existence of a cross of grass-eater hermits having the same name as the Providential Cross of St. Sukiaseans. Later seven grass-eaters were killed by the Persian soldiers, and among them were Polikarpos and Epyphan [46, p. 71].

These facts leave no doubt that the institution (cult?) of grass-eaters existed on a wide area of Armenian lands, and that their symbol was the Providential Cross. Such a form of asceticism is a feature of early Christians.

Although St. Voskeans and St. Sukiaseans are "venerated" saints (they have their feast-commemoration days in the Ritual Calendar), their cult was not of all-Armenian nature but belonged to the population of Bagrevand and its neighboring regions. If the hypothesis about the 40-year-long missionary activity of Sukiaseans is correct, then it must be concluded that a local form of early Christianity had deep roots among the population of those regions. Even being assimilated by the later form of state Christianity preached by St. Gregory the Illuminator and his disciples, it preserved its somewhat archaic traits such as worship of a group of martyrs, grass-eating form of asceticism and the cult of the Providential Cross. There is no data about the ways of spread of that form of Christianity to the southern parts of Vaspurakan - Moks, Sparkert, Shatakh, but some half-legendary stories could have reached it along with the legends about the mythic might of Bahadras' cross, and the representation of xach Patarazin in the epic is a probable reminiscence of such a prefiguration. Given the legends about St. Voskeans and St. Sukiaseans had been shaped long before the Armenian script was invented, they might have been recorded in Greek and might have occured in the writings of Late Antiquity or Early Christian authors (maybe Tatianus), but this question is still vague. They survived first of all due to folk oral tradition, and unknown writers have preserved them in their works dating to the 11-12th centuries. However, oral tradition tends to change and mix, and that is the reason of existence of several variants of the same story and their motifs' occurrence in the epic. 


\section{Remnants of the cult}

Back to the folk-Christian cult of St. Sukiaseans, there are some symbolic representations of St. Sukias and his companions in the folk magical prayers and other sub-genres of folklore. One example is preserved in the manuscript of 18 th century from the collection of Tübingen University library, titled $4 \mathrm{pp}$ hutipph (here - a magic scripture against the stitch in the side or abdominal pain). In the prayer St. Sukiaseans went up to mountains and saw the personalized stitch (embodiment of pain?) sitting on a rock. The saints asked who he was, and he answered that he was khit' $k^{6}$ sitting inside the human sons, chewing their meat and drinking their blood, crushing their bones. Then the saints tried to slay him with a sword but the khit'k' swore in the name of Lord, angels, St. Virgin Mary, St. John the Baptist, St. Stephen the Protomartyr, St. apostles and prophets that if anybody reads or mentions those names will find remedy and no stitch will ever approach him.

The main symbolic point here is the name of a personified disease. The word khit ${ }^{6}{ }^{6}$ or khet' $k$ ' means not only a disease, but also a cave high in the mountains or a rock in the sea [47, p. 364]. For St. Sukiaseans lived on Sukavet and prayed in a cave, they have a special power to exile a disease of khit' $k$.

Trying to find modern manifestations of the cult of St. Sukiaseans, the ethnographic expedition of the Institute of Archaeology and Ethnography of NAS RA was undertaken in July, 2016. The research team discovered its maintenance (traces? Existence?) in the villages Nerkin Getashen and Lichk (Gełarkunik region). It is a newly restored chapel in Nerkin Getashen devoted to St. Sukiaseans (Fig. 1). The major part of the village population is generations of immigrants from Bagrevand province. As Vachagan (Vardges) Sargsian informs, a large family - the clan (azg) of Suk'é (Sukias) - once immigrated to the villages of Nerkin Getashen and neighbouring Lichk, and the chapel of St. Suk'esank' (that is the local variant of the martyrs' name) belongs to that clan as a familiar sanctuary, though everybody may enter there and pray or light candles. Vachagan's own grandmother was from Sukés clan. A young man named Atom formerly performed some magic rites there using seven pebbles, currently stored in the chapel (Fig. 2). He claimed to have received his foretelling powers in a dream, where St. Sukiaseans visited him.

If anybody's hen or chicken falls into the pit of t'onir (oven), there is a tradition to say "Gərt'an Naroz Surb Suk'esank'!", believing that the saints can help the birds to creep through tonir and get out without harm from the ventilation groove. Old stories tell about real cases of hens being saved with the help of the invisible patron-martyrs. There is another true story about a woman who was falsely accused of stealing and eating a hen, but she went to the chapel of St. Sukiaseans, prayed and asked the saints to help her. In the night the real perpetrator's child died, and the neighbor's child realized that the woman was innocent [48].

Although nobody remembers how immigrants founded the new sanctuary devoted to St. Sukiaseans, there is no doubt that they brought their worship 
and tradition from Alashkert. A sacral object or just a stone was taken from the monastery on mountain Sukavet, but any recollections about that did not preserve in people's memory. An obscure testimony is the formula of application to the saints: "Hen Naroz (?) St. Suk'esank", where the meaning of the word "naroz" is also forgotten. The story with the saved hens resembles a similar legend traditionally associated with St. Grigor Narekatsi, called "Dzagaharuyts" (Reanimator of birds) because he saved chickens fallen into tonir [43, p. 306307], and this story about St. Narekatsi is being told even in our days, for example, in Zolakar's (Gegharkunik) St. Grigor Narekatsi or Tsakhkashen's (Aragatsotn) Narek chapels.

The wedding song of praising the bridegroom was still common about 20 years ago in the villages around Martuni inhabited by the descendants of immigrants from Alashkert:

Unıpp Unıptuuuuip quplin ophis,

Utl Uuunndnı qopnıptiunı...

puqnenn puqu $\mathrm{h}$ qlohu, puqqu h qlohu.

Un dnınnuर्unın unh.

Unıpp Unıptiuuuiqp Ulu2litingh

.nıp unıpuini unh...
St. Sukiaseans bless your life

With the might of the only God...

Bridegroom (king) with the wrath on head, Take and turn around,

Let the St. Sukiaseans of Alashkert

Give him luck. [49, p. 83-84].

This, again, testifies the persistence of the ancient tradition despite deportation from the Western Armenia and long period of atheistic propaganda in Soviet times.

\section{Conclusion}

Given the above-mentioned evidence, it follows that at least three different versions of the legendary story about the St. Voskians and Sukiasians (Sukiaseans?) existed simultaneously. Initially, stories on saints of Alanian origin who invented the "grass-eating" form of Christianity, they related exclusively to Bagrevand, later some variations penetrated into Vaspurakan, being merged with the mythic cycle about king Artashes and his family with remnants from the Caucasian epic, and finally were written down by different authors and included in religious and calendar texts with minor corrections. Those legends explain the traditional pilgrimage to the places connected with the St. Voskeans and Sukiasians, the special honor given to them by the people of Bagrevand and Basen.

It is highly probable that missioners of Alanian origin and of royal blood spread the "grass-eating" form of Christianity and the cult of Providential Cross in the Western Armenia. Since they in fact were relatives of the Queen Satenik, that gives a better understanding of historical influence of the Alanian Kingdom on Armenian culture.

The movement of grass-eater early Christians, never confronting with the official Gregorian doctrine, spread to other parts of historical Armenia and reached Vayots 
Dzor and Ararat. Moreover, the St. Sukiaseans could have been the first to invent that form of Christianity. As Bagrevand was "cleared" of Armenians at the beginning of the 2oth century, the St. Voskians and Sukiaseans were almost forgotten. However, the cult of St. Sukiaseans survived in the regions of Eastern Armenia, inhabited by immigrants from Bagrevand, particularly Nerkin Getashen.

\section{REFERENCES}

1. Melikset-Bekov LM. Georgian edition of the story about the "Arajavor" fast [Gruzinskii izvod skazaniya o poste "Aradzhavor"] Petrograd: Publ. of Academy of Sciences, 1917:73-111.

2. Calendar of Feasts, vol. 1. [Tonatsuyts, hator A]. Ejmiadzin: "Surb Grigor Lusavorič", 1774.

3. Alishan Gh. The Dawn of Armenian Christianity [Arshaluys Kristoneutean $\mathrm{Ha}$ yots]. Venice: Mkhitaryan typ., 1901.

4. Calendar of Feasts [Tonatsuyts]. Constantinople: Astvacatur Konstandnupolsecu typ., 1725 .

5. Synaxary [Haysmavurk']. Constantinople: Grigor Marzvanecu typ., 1706.

6. Sofyan AB. Christian Martyrs in Armenia: Three Portraits, Three Destinies [Khristianskiie mucheniki v Armenii: tri portreta, tri sudby]. Religion, Church, Society. Issue III. S. Prilutskiy (ed.). Saint-Petersburg: "Skifia-print", 2014. p. $147-155$.

7. Petrushenko N. (ed.). Lives of Russian Saints [Zhitiya russkikh svyatykh]. Moscow: "Sibirskaya blagozvonnitsa", 2011.

8. Thovma Arcruni. The History of the Dynasty of Artsruni [Patmutyun tann Arcruneac]. Constantinople: Poghos Arapyan Typ., 1852.

9. Hovhannes Draskhanakertci. The Historiography of Hovhan the Catholicos of All Armenians [Patmagrutyun Hovhannu Katotikosi amenayn hayoc']. Jerusalem: Srboc Hakobyanc typ., 1843 .

10. Inchichyan Gh. Geography of Four Sides of the World: Asia, Europe, Africa and America, part 1: Asia, vol. 1 [Ašxarhagrutyun čoric masanc ašxarhi: Asio, Evropio, Apriko ev Ameriko. Masn aradzin: Asia. Hator A]. Venice: Mkhitaryan typ., 1806.

\section{СПИСОК ЛИТЕРАТУРЫ}

1. Меликсет-Бековъ Л.М. Грузинскій изводъ сказанія о посте "Араджаворъ". Петроград: тип. Акад. Наук, 1917. С. 73-111.

2. Календарь праздников. Том 1. Эчмиадзин: Типография Св. Григор Лусаворич, 1774.

3. Алишан $Г$. Заря армянского христианства. Венеция: Типография Мхитарян, 1901.

4. Календарь праздников. Константинополь: Типография Аствацатур Констанднуполсецу, 1725.

5. Синаксарий. Константинополь: Типография Григор Марзванецу, 1706.

6. Софян А.Б. Христианские мученики в Армении: три портрета, три судьбы // Религия, церковь, общество. Вып. III / ред. С. Прилуцкий. СПб.: “Скифия-принт”, 2014. С. 147-155.

7. Жития русских святых: в 2 т. / ред. Н.В. Петрусенко. М.: Сибирская Благозвонница, 2011.

8. Товма Арцруни. История династии Арцруни. Константинополь: Типография Погос Арапян, 1852.

9. Оганес Драсханакерци. Историография Католикоса Всех Армян Огана, Иерусалим: Типография Србоц Акопянц, 1843.

10. Инчичян Г. География четырех частей света: Азии, Европы, Африки и Америки. Первая часть: Азия. Венеция: Типография Мхитарян, 1806.

11. Алишан Г. Арарат. Природа Армении. Венеция: Типография Мхитарян, 1890.

12. Авгерян $M$. Полное собрание житий святых Армянской церкви, которые включены в старый календарь праздников армянской церкви. Том 2, Венеция: Типография Мхитарян, 1811.

13. Инчичян $Г$. Описание древней Армении. Венеция: Типография Мхитарян, 1922. 
11. Alishan Gh. Ayrarat Natural Land of Armenia [Ayrarat bnašxarh Hayastanyayc] Venice: Mkhitaryan typ., 1890.

12. Avgeryan M. Full Hagiography and Martyrology of Saints Who are in Old Celandar of Feast of the Armenian Church, vol. 2 [Liakatar vark' ev vkayabanutyun srboc vork' kan $i$ hin Tonacuci Yeketecvo Hayastaneayc, Hator B]. Venice: Mkhitaryan typ., 1811.

13. Inchichyan Gh. Decription of Ancient Armenia [Storagrutyun hin Hayastaneayc]. Venice: Mkhitaryan typ., 1922.

14. Tataryan HA. Couple of Monasteries (St. Voskeans and St. Sukiaseans Monasteries) [Zuyg mə vank'er (S. Voskeanc ev S. Suk'easeanc vanqerə)]. "Byuzandion" newspaper. Constantinople: № 86, 1897.

15. Géographie de Moïse de Corène d'après Ptolémée / texte arménien, traduit en français par le p. Arsène Soukry. Venise: Imprimerie Arménienne, 1881.

16. Haykuni S. Bagrevand: the Province Dzhrabašx, Part 1. [Bagrevand: Dzrabašx gavar, Masn A]. Vałaršapat: Mayr Ator, 1894.

17. Ukhtavor. Mush Valley [Muši dašto]. "Arevelk" newspaper. Constantinople: № 3929, 1899.

18. Eprikyan S. An Illustrated Dictionary of Natural Land, vol. 1 [Patkerazard bnašxarhik bararan, hator A]. Venice: Mkhitaryan typ., 1902.

19. Matthews Urhayeci. History of Armenians [Hayoc patmutyun]. Yerevan: "Hayastan", 1973 .

20. Hakobyan G. The Ethnography and Folklore of Basen [Baseni azgagrutyunn $u$ banahyusutyunə]. Yerevan: "Hayastan", 1974.

21. Srvandzteants G. On the Old and New: History of Davit and Movses Xorenaci [Hnoc ev noroc: patmutyun vasn Davt'i ev Movsesi Xorenacvo]. Constantinople: M. Tntesyan typ, 1874.

22. Dumezil G. Osetian Epic and Mythology [Osetinskii epos i mifologia]. Moscow: Nauka, 1976.

23. Petrosyan AE. Armenian Satenik/Satinik and Caucasian Satana/Sataney [Armyanskaya Satenik/Satinik i Kavkazskaya Satana/Sataney]. Vestnik Vladikavkazskogo nauchnogo centra. Vladikavkaz. 2016, 16(1): 8-17.

24. Abeghyan M. Commentaries. The Daredevils of Sasun, folk epic, vol. 2, part 2 [Tsa-
14. Татарян А. Пара монастырей (монастыри Св. Воскянов и С. Сукиасянов) // Газ. «Бюзандион». К. Константинополь, № 86, 1897.

15. География Моисея Хоренского по Птолемею Армянские тексты, перевод на французский Арсен Сукри, Венеция: Армянская типография, 1881.

16. Айкуни C. Багреванд. Провинция Джрабашх. Часть 1. Вагаршапат: Майр Атор, 1894.

17. Ухтавор Мушская равнина// Газ. «Аревелк». Константинополь: № 3929, 1899. C. 1.

18. Эприкян С. Иллюстрированный словарь естественной географии. Том 1. Венеция: Типография Мхитарян, 1902.

19. Матевос Урхаеци История Армении. Ереван: «Айастан», 1973.

20. Акопян Г. Этнография и фольклор Басена. Ереван: «Айастан», 1974.

21. Срвандзтянц Г. Из старого и нового. История Давида и Моисея Хоренского, Константинополь: Типография Е.М. Тнтесян, 1874.

22. Дюмезиль Ж. Осетинский эпос и мифология, Москва: «Наука», 1976.

23. Петросян A.E. Армянская Сатеник/ Сатиник и кавказская Сатана/Сатаней. Вестник Владикавказского научного центра. Т. 16, , Владикавказ: № 1. С 8-17.

24. Абегян M. Комментарии// Сасна Црер, народный эпос, том 2, часть вторая, Ереван: «Айпетхрат», 1951. С. 819-893.

25. Книга пятницы и Песнопения Венеция: Типография Акоп Мегапарт, 1512.

26. Пиргалемян Г. Армянские колофоны. Константинополь: Типография Ншан Перперян, 1888.

27. Саркисян Н. Топография Малой и Великой Армении. Венеция: Типография Мхитарян, 1864.

28. Мирахорян M. Описательный путеводитель по армянонаселенным провинциям Восточного Тачкастана. Часть 3. Константинополь: Типография М.К. Сареян, 1885.

29. Срвандзтянц Г. Сочинения, т. 1, Ереван: Типография Академии Наук Армянской CCP, 1978.

30. Лалаян Е. Ара Прекрасный, записано Е. Лалаяном. «Этнографический журнал». Тифлис: вып. IX, 1902. С. 144-159. 
not'agrutyunner. Sasna Crer, jolovrdakan vep, $B$ hator, Masn yerkrord]. Yerevan: "Haypethrat”, 1951. p. 819-893.

25. The Book of Friday and Songs [Urbatagirk ev tałaran]. Venice: typography Hakob Mełapart, 1512.

26. Pirghalemyan Gh. Armenian Colophons [Notark ' hayoc]. Constantinople: Nšan Perperyan typ., 1888.

27. Sargisyan N. Topography of Minor and Major Armenia [Tetagrutyunk'i P'ok'r ev i Mec Hays]. Venice: Mkhitarian typ., 1864.

28. Mirakhoryan M. Description of Journey to Provinces of Eastern Tajkastan Inhabited by Armenians, part 3 [Nkaragrakan ułevorutyun $i$ hayabnak gavars Arevelyan Tajkastani, masn G]. Costantinople: M.K. Sarəyan typ., 1885 .

29. Srvandztyants G. Works, vol. 1 [Yerker, hator 1]. Yerevan: Haykakan SSR Akademiayi typ., 1978.

30. Lalayan Ye. Ara the Beautiful, recorded by Ye Lalayan [Ara Gełecik, gri arav Ye. Lalayan]. "Azgagrakan handes"("Ethnographic Review"). Tiflis. 1902, 9: 144-159.

31. Bense Bulanəx, or Province Hark' [Bulanəx, kam Hark' gavar]. Azgagrakan handes, Tiflis. 1899, 5: 5-184.

32. Shahinyan Sh. Roots of Centuries [Daravor armatner]. Yerevan: "Sovetakan grol", 1980.

33. Ormanyan M. Ritual Dictionary [Tsisakan bararan]. Yerevan: "Hayastan", 1992.

34. Simonyan L. Some Aspects of the Symbol of Cross-Sword [Xach-t'əri xorhrdanšakan imasti voroš kołmer]. "Challenges of XXI century and Armenia”, proceedings of conference. Yerevan: YSU publications, 2011. p. 61-78.

35. Shanaev G. Folk narratives of Caucasian Highlanders [Narodnye skazaniya kavkazskikh gortsev]. Collection of data about the Caucasian Highlanders, issue 9. Tiflis: Tipografiya glavnogo upravleniya namestnika kavkazskogo, 1876. p. 1-64 (234-298).

36. Griswar J. "Le motif de l'epee jetèe au lac: la mort d'Arthur et la mort de Batraz". Romania. Paris: № 9, 1969. p. 289-340.

37. Legends of Narts. Ossetian Epic [Skazaniya o nartax. Osetinskii epos] Yu. Lebedinskyi (transl.). Moscow: "Sovetskaya Rossia", 1978.

38. Scott Littleton C, Malcor LA. From Scythia to Camelot [Ot Skifii do Kamelota]. Moscow: "Manager", 2007.
31. Бенсе Буланых, или провинция Харк. «Этнографический журнал». Тифлис: вып. 5, 1899. С. 5-184.

32. Шагинян Ш. Вековые корни. Ереван: «Советакан грох», 1980.

33. Орманян M. Ритуальный словарь, Ереван: «Айастан», 1992.

34. Симонян Л. Некоторые аспекты символического значения креста. Сборник материалов конференции «Религиозные вызовы XXI века и Армения». Ереван: Издательство ЕГУ, 2011. С. 61-78.

35. Шанаев $Г$. Народныя сказанія кавказскихъ горцевъ, Сборникъ Сведеній о кавказскихъ горцахъ. Тифлис: Типография главного управления наместника кавказского, 1876. C. 1-64 (234-298).

36. Грисвар Дж. «Мотив меча, закинутого в озеро: смерть Артура и смерть Батраза»// Романия №9, 1969. с. 289-340.

37. Сказания о нартах. Осетинский эпос, пер. Ю. Лебединского, Москва: «Советская Россия», 1978.

38. Скотт Литтлтон К., Малькор Л.А. От Скифии до Камелота, Москва: «Менеджер», 2007.

39. Абаев В. Нартовский эпос осетин// Сказания о нартах. Осетинский эпос. Москва: «Советская Россия», 1978. с. 5-42.

40. Козин C.A. Сокровенное сказание: Монгольская летопись 1240 г. под именем Чжан Чао Би Ши, Москва-Ленинград: Издво Академии Наук, 1941.

41. Сейлан Сасун. Журнал «Мурч». Тифлис: № 5, 1895. С. 634-663.

42. Срвандзтянц Г. Сочинения, т. 2, Ереван: Изд-во Академии Наук Арм. ССР, 1982.

43. Ганаланян А. Сказания. Ереван: Издво Академии Наук Арм. ССР, 1969.

44. Степанос Орбелян. История провинции Сисакан, Париж: Типография Шахназарянц, 1859.

45. Овсепян Г.В. Ювелирное изделие XIII века (Святой Символ Травоедов), Журнал «Гехарвест», Тифлис: № 4, 1911. С. 37-44:

46. Ован Мамиконян. История Тарона в переводе Зеноба Сирийца. Венеция: Типография Мхитарян, 1889.

47. Ачарян Р. Корневой словарь армянского языка. Т. 2. Ереван: Издательство ЕГУ, 1973. 
39. Abaev V. The Narts' epic of Ossetians [Nartovskii epos osetin]. Legends of Narts. Ossetian epic. Moscow: "Sovetskaya Rossia", 1978: 5-42.

40. Kozin SA. The Mystic Story: A Mongolian Chronicle of 1243 entitled Juan Chao Bi Shi. Vol. 1 [Sokrovennoye skazanie: Mongolskaya khronika $1240 \mathrm{~g}$. pod nazvaniem Yuan Chao Bi Shi]. Moscow-Leningrad: Academia Nauk Publ., 1941.

41. Seylan Sasun. "Murch" journal, Tiflis. 1895, 5: 634-663.

42. Srvandztyants G. Works, vol. 2 [Yerker, hator 2]. Yerevan: HSSR Gitutyunneri Academia Publ., 1982.

43. Ganalanyan A. Legends [Avandapatum]. Yerevan: HSSR Gitutyunneri Academia, 1969.

44. Stepanos Orbelyan. History of the Province Sisakan vol. 1 [Patmutyun nahangin Sisakan hator A] Paris: K.V. Shahnazaryants typ., 1859.

45. Ovsepyan G. Goldsmith Art of the 13th century (The Holy Symbol of Grass-Eaters) [Voskerchutyan aruesti mi nmuš JG darum (Xotakerac S. Nšan)]. Gełarvest, Tiflis. 1911, 4: 37-44.

46. Ovan Mamikonyan. History of Taron translated by Zenoba the Assyrian [Patmutyun Tarono zor t'argm. Zenob Asori]. Venice: Mkhitarian typ., 1889.

47. Acharyan H. Etymological Dictionary of Armenian Language vol. 2 [Hayeren armatakan bararan hator B]. Yerevan: Yerevani hamalsarani hrat., 1973.

48. Simonian L, Oganesyan K, Avetisyan L. Field ethnographic materials of the Expedition Sevan-Lichk. Institute of Archaeology and Ethnography of NAN RA, July, 2016.

49. Haykuni S. Folk songs, proverbs, riddles etc. [Jołovrdakan yerg, arac, haneluk ev ayln]. Eminean azgagrakan jolovacu, issue 6. Moscow-Vałaršapat: Varvary Gatsuk typ., 1906.
48. Симонян Л., Оганесян К., Аветисян Л. Полевые этнографические материалы экспедиции «Севан-Личк», июль 2016, Институт археологии и этнографии НАН РА.

49. Айкуни C. Народная песня, пословица, загадка и др., Эминианский этнографический сборник. Вып. 6. Москва-Вагаршапат: Типография Варвары Гатцук, 1906.

Статья поступила в редакцию 19.06.2021 2. 